\title{
UPAYA PENINGKATAN AKTIVITAS ORGANISASI PADA CV. BERSAUDRA PALEMBANG
}

\author{
Akila *) \\ ABSTRAK
}

\begin{abstract}
Tujuan penelitian ini untuk mengetahui pelaksanaan pembagian kerja dan pendelegasian wewenang pada CV. Bersaudara Palembang. Metode yang digunakan dalam penelitian ini adalah deskriptif kualitatif. Sumber data dalam penelitian adalah data primer dan data sekunder .Teknik pengumpulan data dengan dalam penelitian ini yaitu mengamati secara langsung terhadap masalah yang diteliti dengan tujuan agar masalah dapat diketahui dan dipahami.

Hasil penelitian menunjukkan bahwa pembagian pekerjaan yang seharusnya dikerjakan oleh bagian penjualan barang, kenyataannya bagian pembukuan ikut bertugas pada bagian penjualan barang, Mengatasi masing-masing bagian tidak mencapuri tugas-tugas yang telah ditetapkan oleh pimpinan, sehingga bagian lain mempunyai kesempatan untuk memahami dan melaksanakan tugas secara tegas dan jelas. Pimpinan sebaiknya tidak mengabaikan ketiga prosedur pebagian kerja. Pelimpahan wewenang, belum dilaksanakan sebagaimana mestinya, tugas yang semestinya dilakukan bagian bendahara masih sering dikerjakan oleh pimpinan itu sendiri. Mengatasinya pimpinan tidak mencampuri lagi dan menyerahkan tugas tersebut kepada bagian bendahara sepenuhnya, agar pekerjaan dapat berjalan sebagaimana mestinya tanpa adanya keraguan dalam melaksanakan tugasnya.
\end{abstract}

Kata kunci : Pembagian kerja, pendelegasian wewenang

I. PENDAHULUAN

\section{A. Latar Belakang Masalah}

$\mathrm{Di}$ Indonesia dewasa ini perkembangan manajemen dinilai cukup menggembirakan dengan banyaknya lembaga-lembaga atau badan yang menyediakan pendidikan dan latihan manajemen serta kursuskursus manajemen.

$$
\text { Manajemen }
$$

memegang

peranan penting didalam menunjang usaha terciptanya sasaran pembangunan nasional. Pembangunan akan berjalan lancar dan baik, diperlukan adanya sumber daya manusia, administrasi yang teratur, baik itu instansi pemerintah maupun perusahaan-perusahaan swasta yang semuanya membutuhkan manusia yang terampil. Manusia sebagai anggota organisasi dituntut untuk menyumbangkan pikiran dan tenaga dan ide-ide untuk mencapai tujuan yang telah ditetapkan. Untuk mencapai tujuan ini diperlukan peran serta semua pihak baik pemerintah maupun pihak swasta. Meskipun demikian diakui didalam operasinya masih terdapat kepincangankepincangan. Keadaan ini mengisyaratkan bahwa upaya menerapkan sistem manajemen yang tepat baik di lingkungan oragnisasi sosial masyarakat maupun kalangan badan-badan usaha lainnya perlu dilaksanakan. Kualitas sumber daya manusia merupakan faktor penting dalam mencapai keberhasilan perusahaan, upaya untuk mengembangkan kualitas sumber daya manusia terus menerus dikembangkan.

Organisasi digunakan sebagai tempat atau wadah dimana orangorang berkumpul. Organisasi juga merupakan tempat untuk bekerja sama secara rasional dan sistematis yang meliputi kegiatan yang terencana, terorganisasi, terpimpin dan terkendali dalam upaya memanfaatkan sumber daya yang digunakan secara efisien dan efektif untuk mencapai tujuan organisasi. Organisasi mencerminkan adanya kerja sama antara beberapa 
orang yang membentuk kelompok atau kerja sama dengan maksud mencapai tujuan yang telah disepakati.

$$
\text { Menurut Umam (2010) }
$$

mengemukakan bahwa organisasi adalah tempat atau wadah orangorang berkumpul, bekerja sama secara rasional dan sistematis, terencana, terorganisasi, terpimpin dan terkendali dalam lingkungan, (sarana-prasarana, data, dan lain-lain) secara efisien dan efektif untuk mencapai tujuan yang telah ditentukan. Menurut Manulang (2008) manajemen adalah sebagai suatu proses, kolektivitas orang-orang yang melakukan aktivitas manajemen dan manajement sebagai seni fungsi untuk mencapai tujuan-tujuan yang nyata mendatangkan hasil.Pendapat G.R. Terry ada 4 komponen pokok dari suatu organisasi formal yaitu : 1) Adanya pembagian kerja, 2) Adanya penentuan kualifikasi orang-orang yang ditugaskan untuk melaksanakan pekerjaan yang dibagi-bagikan, 3)Adanya lingkungan yang memungkinkan pekerjaan tersebut dapat dilaksanakan, dan 4) Adanya hubungan antara orang-orang didalam suatu kelompok kerja dan begitu pula hubungan antara kelompok kerja lainnya. Dari defenisi ahli tersebut disimpulkan manajemen metitik beratkan pada usaha memanfaatkan orang lain dalam mencapai tujuan, untuk mencapai tujuan tersebut maka orang-orang didalam organisasi harus jelas wewenang dan tugas pekerjaannya

$$
\text { Di dalam mencapai tujuan }
$$

pimpinan selalu berusaha sekuat tenaga untuk mengkoordinir dan mengkombinasikan aktivitas-aktivitas secara efektif dan efesien. Menjalankan suatu aktivitas akan mengalami suatu hambatan dan permasalahan, baik permasalahan yang berasal dari luar maupun dari dalam perusahaan itu sendiri.
Pimpinan perusahaan dalam menjalankan aktivitasnya mempunyai tanggungjawab terhadap keberhasilan perusahaan untuk mencapai tujuan tersebut, maka pimpinan perusahaan selalu dituntut bekerja dengan segala kemampuan untuk mengatasi masalah yang dihadapi perusahaan khusunya perusahaan bersaudara palembang. Di dalam perusahaan pelaksanan pembagian kerja harus jelas dan pendelegasian wewenang harus jelas, sehingga pelaksanan kegiatan yang diharapkan tidak menjadi terhambat.

Dengan berdasarkan uraian diatas maka penulis tertarik untuk meneliti dengan judul "Upaya Peningkatan Aktivitas Organisasi Pada Perusahaan Bersaudara Palembang".

\section{B. Pembatan dan Rumusan Masalah}

1. Pembatasan Masalah.

Agar penelitian tidak terlalu luas dan lebih terarah dan tidak menyimpang dari permasalah, maka peneliti membatasi pembahasan yang ada di dalam organisasi yaitu kurang jelasnya pelaksanaan pembagian kerja dan pelimpahan wewenang.

2. Rumusan Masalah Berdasarkan latar belakang diatas, maka dirumuskan masalah dalam penelitian ini adalah "Bagaimanakah pelaksanaan pembagian kerja dan pendelegasian wewenang pada CV. Bersaudara Palembang ".

\section{Tujuan Penelitian}

Penelitian ini bertujuan untuk mengetahui pelaksanaan pembagian kerja dan pendelegasian wewenang pada CV. Bersaudara Palembang ". 


\section{Kontribusi Penelitian}

Hasil penelitian ini daharapkan bermanfaat:

1. Memberikan sumbangan pemikiran dan perkembangan ilmu pengetahuan, khusunya yang berhubungan dengan peningkatan sumber daya manusia.

2. Sebagai bahan masukan bagi pimpinan CV. Bersaudara Palembang khususnya dalam upaya meningkatkan aktivitas organisasi.

3. Melengkapi dan memperluas teori yang sudah diperoleh melalui penelitian lain sebelumnya dan menambah wawasan penulis dan peneliti lain dalam pengembangan ilmu pengetahuan.

\section{E. Metode Penelitian}

Dalam penelitian menggunakan metode deskriptif kualitatif yaitu untuk meluaskan sifat suatu keadaan yang diteliti dengan jalan mengumpulkan data yang lengkap dan kemudian mengelolahnya, sehingga dapat mengambil kesimpulan yang mendekati kebenaran.

Sumber data dalam penelitian adalah data primer dan data sekunder. Teknik pengumpulan data dalam penelitian yaitu : 1) observasi adalah dengan melakukan pengamatan secara sistimatik terhadap kegiatan yang ada untuk memperoleh hasil sesuai dengan tujuan. 2) Interview adalah wawancara langsung dengan pimpinan perusahaan yang memberikan informasi berhubungan data diperlukan. 3) Library Reseach adalah data yang diperoleh dari perpustakaan berupa literatur dan informasi yang berhubungan penelitian.

\section{Tinjauan Pustaka}

\section{A. Pengertian Manajemen.}

Mengenai istilah manajemen sampai saat ini belum ada keseragaman. Berbagai istilah yang digunakan seperti, ketatalaksanaan, kepemimpinan, kepengurusan dan lain sebagainya. Untuk mendapatkan gambaran yang jelas tentang pengertian yang terkandung dalam manajemen sebagai berikut : Menurut Manulang (2008)

1. Manajemen sebagai suatu proses, manajemen sebagai kolektivitas orang-orang yang melakukan aktivitas manajemen, manajemen sebagai suatu seni dan sebagai suatu ilmu.

2. Manajemen sebagai kolektivitas orang-orang yang melakukan aktivitas manajemen.

3. Manajement sebagai seni fungsi untuk mencapai tujuan-tujuan yang nyata mendatangkan hasil.

George R. Terry menyatakan manajemen adalah pencapaian suatu tujuan yang ditetapkan terlebih dahulu dengan mempergunakan kegiatan orang lain.

Berdasarkan pendapat ahli disimpulkan bahwa manajemen adalah seni dan ilmu perencanaan, pengorganisasian, penyusunan, pengarahan dan pengawasan dari sumber daya, terutama sumber daya manusia untuk mencapai tujuan yang sudah ditetapkan terlebih dahulu. Dengan kata lain, manajemen terdiri dari fungsi-fungsi yang saling berhubungan (fungsi fundamental dari pada manajemen) sedangkan pengorganisasian, penggerakan dan pengarahan serta pengawasan.

\section{Prinsip-prinsip Manajemen.}

Menurut Manulang (2008) ada 14 prinsip manajemen yang perlu diterapkan dalam pelaksanaan tugas sebagai berikut : 
1. Pembagian Kerja.

Masing-masing orang harus jelas apa yang harus dikerjakan dan diferensiasi tugas inilah yang membedakan seseorang didalam suatu badan tertentu, apakah ia pimpinan, pelaksanaan staff dan lain sebagainya.

2. Kekuasaan (wewenang) dan tanggung jawab (authority and responsibility).

Setiap pejabatan harus mempunyai kekuasaan dan tanggung jawab, kekuasaan, wewenang adalah hak untuk mengambil keputusan, tanggung jawab atau pekerjaan yang harus dikerjakannya.

3. Disiplin (discipline)

Disiplin hanya ada dalam suatu badan, bila setiap penjabatan dalam badan tersebut mentaati peraturan-peraturan yang dibuat, baik pimpinan maupun pelaksana. Atasan harus memberikan teladan kepada bawahan dengan jalan mematuhi peraturan-peraturan dan perjanjian-perjanjian yang tealh dibuat.

4. Kesatuan Perintah (Unity of comand).

"One employee to have orders from one superrior only", yaitu bahwa seorang pegawai menerima perintah dari atasan saja.

5. Kesatuan Arah (Unity of direction) Bahwa tujuan masing-masing unit, dan tujuan sesuatu badan sebagai keseluruhan tidak boleh bertentangan satu sama lainnya.

6. Kepentingan individu harus berada di bawah kepentingan umum (Subordinate of individual interest to general interest).

Prinsip ini sudah menjelaskan diri sendiri, kepentingan umum harus diatas kepentingan pribadi.

7. Pembayaran upah yang adil (Remuneration of pernonnel).
Dalam memberikan upah kepada para pegawai, harus diperhatikan keadilan. Adil berarti tidak berat sebelah, ada dasar objektif dalam menetapkan upah masing-masing.

8. Pemusatan dan sentralisasi.

Berbagai jenis wewenang yang harus dipusatkan, sebaliknya berbagai jenis wewenang dapat di bagi-bagi.

9. Rantai skala ata Scalar cahin (line if authority).

Prinsip ini garis wewenang dalam suatu organisasi harus jelas.

10. Tata tertip (Order)

Prinsip ini bawahan harus ada ketertiban baik material maupun orang-orang.

11. Keadilan (Equity)

Agar setiap bawahan setia kepada atasannya, masing-masing harus mempraktekkan keadilan yakni memberikan kepada setiap orang apa yang menjadi haknya.

12. Stabilitas pegawai (Stability of tenure of personnel).

Prinsip ini dimaksud bahwa dalam sesuatu badan haruslah dijaga stabilitas pegawai, jangan terlalu sering pengganti pegawai, baik karena perpindahan atau pemecatan. Ketidak stabilan pegawai menimbulkan pertambahan biaya baik untuk merekrut, melatih dan juga untuk pengawasan.

13. Insiatif (Initiative).

Kepada setiap orang harus diberi kesempatan untuk mengungkapan atau menjalankan inisiatif, baik mengenai cara kerja, prosedur kerja atau menjalankan rencanarencana baru didalam pelaksanaan pekerjaanpekerjaannya.

14. Jiwa Kesatuan (Esprit de corps)

Pada dada setiap pejabat dalam suatu organisasi tertentu, haris tertanam jiwa kesatuan atau 
kesetiaan pada kelompok. Kesetiaan merupakan kerjasama pada sejumlah orang untuk mencapai tujuan.

\section{Pengertian Organisasi}

Daft dalam Achmad Sobirin (2007) mengemukakan bahwa organisasi adalah sebuah entitas sosial yang berorientasi pada tujuan dengan suatu sistem kegiatan yang struktur dan mempunyai batas-batas yang bisa terindentifikasi.

Mooney dalam Fathoni (2006) mengatakan bahwa organisasi timbul bila mana orang-orang bergabung dalam usaha mereka untuk mencapai tujuan bersama.

\section{Menurut}

Umam

(2010)

mengemukakan bahwa organisasi adalah tempat atau wadah orangorang berkumpul, bekerja sama secara rasional dan sistematis, terencana, terorganisasi, terpimpin dan terkendali dalam lingkungan, (sarana-prasarana, data, dan lain-lain) secara efisien dan efektif untuk mencapai tujuan yang telah ditentukan.

Pendapat

Sondang $P$. Siagian,(1974) Organisasi adalah setiap bentuk persekutuan antara dua orang atau lebih yang bekerjasama untuk mencapai tujuan bersama yang terikat secara formal dalam ikatan hirarki di mana selalu terdapat gabungan antara orang atau kelompok yang disebut pimpinan dan seorang atau kelompok orang yang disebut bawahan.

Berdasarkan dari pendapat ahli tersebut, unsur-unsur yang membentuk organisasi sebagai berikut:

1. Adanya tujuan bersama.

2. Adanya kerjasama dua orang atau lebih.

3. Adanya pembagian tugas.

4. Adanya kehendak untuk bekerjasama.
Dengan demikian dapat disimpulkan bahwa Organisasi adalah kerja sama antara orang-orang atau sekelompok orang yang memiliki hubungan satu sama lain yang ingin mencapai tujuan bersama.

\section{Indikator-Indikator Organisasi}

Indikatir-indikator organisasi menurut Riduwan (2011) sebagai berikut :

1. Kepatuhan terhadap prosedur kerja

Diharapkan karyawan selalu mengikuti prosedur kerja yang telah diharapkan oleh atasan untuk dalam rangka melaksanakan tugas. Aturan kerja yang jelas sangat dibutuhkan karyawan sebagai pedoman untuk menyelesaikan tugas yang diharapkan.

2. Kepatuhan terhadap jam kerja Disini diharapkan karyawan datang ketempat kerja tepat waktu sesuai dengan jam kerja yang ditentukan. Selain itu apabila karyawan hendak meninggalkan tugas rutin harusnya karyawan meminta izin keatasan sebagai perwujudan disiplin dan kepatuhan waktu kerja.

3. Kepatuhan terhadap Perinta atasan

Didalam melaksanakan tugas, karyawan hendaknya dapat melaksanakan pekerjaan sesuai aturan-aturan yang telah ditetapkan oleh atasannya, sebagai wujud karyawan patuh terhadap perintah atasannya.

\section{Prinsip-prinsip Organisasi.}

Pendapat Manulang (2008) Agar suatu organisasi dapat berjalan dengan baik, perlu dipedomani beberapa azas sebagai berikut

1. Perumusan tujuan dengan jelas.

Bilamana akan melakukan suatu aktivitas, maka harus jelas : apa 
yang menjadi tujuan aktivitas tersebut. Demikian pula bila mengorganisasikan atau membuat suatu skema organisasi atau bentuk suatu badan, harus jelas apa yang menjadi tujuan itu, karena hal tersebut perlu dijadikan, pedoman kearah mana organisasi itu akan dibawa, landasan bagi organisasi yang bersangkutan, menentukan macam aktivitas yang akan dilakukan,menentukan program, prosedur dan koordinasi, semplikasi, sikronisasi dan mekanisasi.

2. Pembagian tugas dan pekerjaan.

Didalam sebuah organisasi, pembagian tugas mutlak diperlukan, tanpa pembagian tugas kemungkinan terjadi tumpang tindih akan menjadi amat besar.

Pembagian tugas pada akhirnya akan menghasilkan departemendepartemen job description dari masing-masing departemendepartemen sampai unit terkecil dalam organisasi. Dengan adanya pembagian tugas, sekaligus ditetapkan susunan organisasi (struktur organisasi), Tugas dan fungsi masing-masing unit dalam organisasi, hubungan-hubungan serta wewenang masing-masing unit organisasi.

3. Delegasi kekuasaan.

Delegasi kekuasaan merupakan keahlian pimpinan yang terpenting, sebab dengan delegasi kekuasaan seseorang pemimpin dapat melipat gandakan waktu, perhatian dan pengetahuan yang terbatas.

4. Rentang kekuasaan.

Dengan rentang kekuasaan dimaksud berapa jumlah orang yang tepat untuk menjadi bawahan seseorang pemimpin, sehingga pemimpin itu dapat memimpin, secara berhasil dan berdaya guna.
5. Jenjang pengawasan

Pada tingkat pengawasan ini harus diusahakan agar organisasi sesederhana mungkin, sehingga memudahkan komunikasi agar ada motivasi, setiap orang dalam organisasi untuk memcapaijenjang tertinggi di dalam struktur organisasi.

6. Kesatuan perintah dan tanggung jawab.

Seorang bawahan hanya mempunyai seorang atasan dari siapa ia menerima perintah dan kepada siapa ia memberi pertanggungjawaban atas pelaksanaan tugasnya.

7. Koordinasi.

Adanya pembagian tugas pekerjaan dan bagian-bagian serta unit terkecil dalam suatu organisasi, cenderung timbul kekuatan memisahakan diri dari organisasi secara keseluruhan.

\section{Pendelegasian Wewenang}

Dalam hal ini pelimpahan terdapat posisi jabatan seperti manajer, sekeretaris, bendahara dan bawahan. Oleh karena kemampuan dan waktu yang terbatas, maka untuk kelancaran tugas pekerjaan yang dipimpin perlu kiranya melimpahkan tugas-tugas tersebut kepada bawahan.

Menurut Louis A.Allen, (1985) pelimpahan wewenang ada 2 (dua) sebagai berikut :

1. Desentralisasi adalah sebagian delegasi-delegasi wewenang yang sistimatik dan selaras kepada tarap operatif perusahaan mewajibkan semua manajer untuk memberikan wewenang kepada taraf-taraf terendah di dalam perusahaan.

2. Sentralisasi adalah pemusatan wewenang pada taraf-taraf tertinggi dari perusahaan. Dalam suatu perseorangan yang 
disentralisasikan keputusan diambil oleh manajemen tertinggi.

Prinsip pokok dalam pemberian wewenang adalah wewenang yang diberikan harus sebanding dengan tugas dan kewajiban yang harus dilaksnakan, semakin bawah tingkat eselon suatu organisasi, maka semakil kecil pula wewenang yang harus diberikan kepadanya. Dengan demikian bearti perusahaan yang bersangkutan harus mulai memikirkan adanya pendelegasian wewenang.

Untuk mendelegasikan wewenang secara efektif Lous A Alen dalam buku "managemen and Organition" mengemukakan bahwa pendelegasian wewenang harus dilakukan dengan teknik khusus sebagai berikut : Pendapat T.Hani Handoko (1985).

1. Tetapkan tujuan.

2. Tugas tanggung jawab dan wewenang.

3. Berikan motivasi kepada bawahan.

4. Meminta penyeleseian kerja.

5. Adanya penyawasan yang memadai.

Pelimpahan wewenang pada perusahaan dimaksud agar adanya kesatuan komando yang menggambarkan siapa yang berhak memberikan perintah atau wewenang. Kepada siapa personil, dilaksanakan, dipatuhi dalam pertanggung jawaban wewenang yang diberikan.

\section{Struktur Organisasi}

Struktur organisasi yang tepat bagi suatu perusahaan belum tentuk baik bagi perusahaan lain. Suatu dasar yang digunakan dalam penyususan struktur organisasi adalah perimbangan bahwa organisasi itu harus fleksibel dalam arti adanya kemungkinan penyesuaianpenyesuaian tampa harus mengadakan perubahan total. Selain itu organisasi yang disusun harus menunjukkan garis-garis wewenang dan tanggungjawab yang jelas. Dengan adannya struktur organisasi yang ada pada perusahaan, maka para bahawan akan mendapat tugas dan perintah yang harus dikerjakan serta dipertangungjawabkan.Untuk itu setiap karyawan harus mengatahui dari siapa ia akan mempertanggungjawabakan hasil kerjanya, dengan kata lain harus ada komunikasi yang tegas. Sesuai dengan prinsip organisasi maka betapapun kecilnya suatu struktur organisasi seharusnya mempunyai tujuan serta perencanaan dalam suatu operasinya.

Menurtu G.R.Terry Struktur organisasi dapat dipandang sebagai kerangka menyeluruh yang menghubung-hubungkan fungsi-fungsi dari suatu badan usaha dan menetapkan hubungan-hubungan yang tetap di antara pegawai-pegawai yang melaksanakan fungsi masingmasing.

Dalam hal ini untuk mencapai efektivitas dan efesiensi kerja, diperlukan jaringan hubungan yang baik diantara bawahan maupun antara atasan dengan bawahan dan antara kegiatan bagian-bagian dalam struktur organisasi sehingga terjadi koordinasi yang serasi dan seimbang antara satu bagian dengan bagian lainnya. Menurut T.Hani Handoko, Unsur-unsur dari struktur organisasi sebagai berikut :

1. Spesialisasi kegiatan berkenaan dengan spesialisasi tugas-tugas individual dan kelompok kerja dalam organisasi (pembagian kerja) dan pengaturan tugas-tugas tersebut menjadi satuan-satuan kerja.

2. Standarisasi kegiatan, merupakan prosedur-prosedur yang digunakan organisasi untuk menjamin 
terlaksananya kegiatan seperti yang direncanakan.

Dalam pelaksanaan pembagian kerja diatur suatu prosedur persiapan kerja yang merupakan "Rules of the game" yang wajib dipahami, dimengerti, diterima serta ditaati oleh seluruh pekerjaan dalam organisasi. Prosedur persiapan kerja sebagai berikut:

a.Pengaturan pembagian kerja yang jelas dan tegas diantara masingmasing satuan organisasi.

b.Pengaturan hubungan kerjasama antara satuan organisasi.

c. Pengaturan tentang garis wewenang dan pertanggungjawaban.

\section{PEMBAHASAN}

Organisasi merupakan bentuk persekutuan antara dua orang atau lebih yang bekerja sama untuk mencapai tujuan, serta mewujudkan misi pokok dari organisasi tersebut diperlukan pelaksanaan dari sebagai fungsi pada bagian yang ada dalam organisasi yang bersangkutan. Untuk diperlukan adanya pembagian kerja atas tugas agar semua kegiatan yang terdapat dalam organisasi dapat dilaksanakan menurut pelaksanaannya. Pembagian tugas merupakan langka pertama didalam pembentukan suatu organisasi suatu perusahaan.

Pembagian kerja adalah rincian tugas pekerjaan agar setiap individu dalam organisasi bertanggung jawab untuk melaksanakan sekumpulan kegiatan yang terbatas. Pelaksanaan pembagian kerja atau tugas berlandaskan atas pertimbangan dan tujuan perusahaan, tenaga kerja, pelayanan, biaya dan peralatan yang digunakan, waktu, barang yang bermutu tinggi dan lain sebagainya. Pembagian kerja dapat dikatakan efisien apabila pelaksaan kerja selalu diarahkan untuk menghindari pemborosan pembagian kerja untuk menjamin terciptanya koodinasi setepat-tepatnya. Pembagian kerja berperan sebagai tindak awal dari pada pengorganisasian suatu badan usaha.

Dalam rangka pembagian mencapai efesiensi dan efektivitas usaha, maka pembagian tugas dan fungsi masing-masing pelaksanaan secara teknis CV.Bersaudara Palembang.

Menajer sebagai pimpinan tertinggi bertugas memimpin, mengawasi pelaksaan tugas karyawan, mempimpin rapat, memberikan keputusan, mengesahkan semua surat-surat yang meliputi surat masuk dan keluar, bersama bendahara menandatangani suratsurat yang menyangkut keuangan. Sektariat tugasnya, mengarsipkan surat-surat, menyusun laporan, bertanggung jawab bidang administrasi dan lain-lain. Bendara bertugas menerima dan mengeluarkan dana, merencanakan anggaran belanja dan pendapatan,memelihara harta kekayaan, bersama-sama manajer menandatangani bukti pengeluaran, bertanggungjawab mengenai keuangan dan administarsi. Perdangan barang bertugas mengkoordinir kegiatan yang berhubungan dengan perdagangan barang, menjual dan membeli barang, menghimpun barang. Tugas pembukuan melaksanakan pembukuan sesuai dengan sistem dan prosedur yang telah ditetapkan berdasarkan bukti-bukti pembukuan secara ketentuan, menyapkan laporan keuangan.

Meskipun setiap tugas yang ada sudah digariskan secara jelas dan tegas, namun pada kegiatannya sehari-hari dijumpai adanya tugas yang dirangkap. Hal dilihat dari kondisi yang ada, dimana pembagian kerja 
atau tugas dibidang usahanya yang terdiri dari beberapa bagian, masingmasing bagian sudah digariskan dengan jelas. Akan tetapi pelaksanaanya tidak demikian, pekerjaan yang seharusnya dikerjakan oleh bagian penjualan barang, pada kenyataannya masih ikutnya bagian pembukuan dalam hal penjualan barang yang bukan menjadi tugasnya. Keadaan yang demikian akan mengakibatkan terjadinya tumpangan tindih dalam pelaksanaan tugas, sehingga tidak ada keharmonisan dalam bekerja.

Untuk melaksanakan aktivitas organisasi, agar semua karyawan mengetahui tugas dan tanggung jawab masing-masing. Pembentukan suatu organisasi formal, karena penentuan wewenang dan tanggung jawab tiap bagian yang telah dibentuk hubungan antara bagian-bagian untuk mengkoordinasikan kegiatan organisasi.

Didalam

pelaksanaan kerja atau tugas diatur prosedur persiapan kerja yang meliputi, pengaturan pembagian kerja yang jelas dan tegas diantara masingmasing satuan organisasi, pengaturan tentang garis wewenang dan tanggung jawab.Sedangkan didalam suatu perusahaan tidak ada keharmonisan kerja, akan mengakibatkan terlambatnya penyelesaian tugastugas yang dikerjakan.

Dalam hal ini dapat diatasi kalau masing-masing bagian tidak mencapuri tugas-tugas yang telah ditetapkan oleh pimpinan, sehingga bagian lain mempunyai kesempatan untuk memahami dan melaksanakan tugas secara tegas dan jelas. Pimpinan sebaiknya tidak mengabaikan ketiga prosedur pebagian kerja.

Pendelegasian atau pelimpahan wewenang, semakin besarnya suatu organisasi, maka akan semakin banyak hambatan yang akan dihadapi. Dalam keadaan ini tugas pimpinan akan semakin banyak pula, untuk itu pimpinan memerlukan bantuan orang lain dalam menangani sebagian dari tugas-tugasnya.

Dengan demikian perusahaan yang bersangkutan harus memikirkan adanya pelimpahan wewenang. Karena pelimpahan wewenang yaitu meyerahkan dari tugas-tugas manajer, yang kurang penting kepada bawahannya yang dipercaya, dan untuk itu disertai pula wewenang dan tanggung jawab. Keterbatasan kemampuan seorang pimpinan untuk melaksanakan tugas-tugas yang berhubungan dengan kepentingan organisasi, karena pada saat tertentu seorang pemimpin harus meninggalkan tugasnya baik tugas luar maupun urusan lainnya dalam perusahaan.

Pada

Palembang,

CV. Bersaudara pendelegasian wewenang belum dilakukan sebagaimana mestinya. Hal ini disebabkan perusahaan belum mempunyai kepercayaam sepenuhnya terhadap kemampuan bawahannya seperti bendahara. Wewenang telah diberikan pada bendahara, tetapi pimpinan perusahaan masih ikut campur dalam hal keuangan. Untuk mengatasinya pimpinan tidak mencampuri lagi dan menyerahkan tugas tersebut kepada bagian bendahar sepenuhnya, agar pekerjaan dapat berjalan sebagaimana mestinya tanpa adanya keraguan dalam melaksanakan kegiatan.Pimpinan yang memberikan wewenang tidak boleh menuntut tanggungjawab dari wewenang yang diberikan kepada bawahan atau tidak boleh menuntut tanggung jawab dari hasil yang diharapkan.

Pendelegasian wewenang berjalan dengan efektif hendaknya 
kesediaan manajemen, untuk melaksanakan tugas yang dilimpahkan kepadanya, pimpinan harus menerima adanya perbedaan cara pemecahan suatu hambatan, dan kemungkinan bawahan akan membuat kesalahan dalam melaksanakan tugasnya. Mereka harus dibiarkan untuk mengembangkan pemecahan masalah suatu hambatan, dan kemungkinan bawahan akan akan membuat kesalahan dalam melaksakan tugasnya. Meraka harus dibiarkan untuk mengembangkan pemecahan masalahnya sendiri dan belajar dari kesalahan mereka. Kesalahan bawahan seharusnya tidak mengurangi delegasi akan tetapi memberikan latihan atau dukungan yang kepada bawahan. Selanjutnya pengembangan komunikasi antara pimpinan dengan bawahan komunikasi antara pimpinan dengan bawahan, akan meningkatkan saling pengertian dan mebuat delegasi lebih efektif. Pimpina perusahaan yang mengetahui kemampuan bawhannya dapat, menentukan tugas-tugas, mana yang dapat didelegasikan kepada bawahan. Bawahan perlu diberi dorongan untuk menggunakan kemampuan dan memberikan semangat dalam menerima taggung jawab.

\section{KESIMPULAN DAN SARAN}

Berdasarkan uraian-uraian di atas, maka penulisan mencoba untuk mengambil kesimpulan dan kemudian penulis akan memberikan saran-saran yang mungkin dapat digunakan sebagai bahan pertimbangan bagi $\mathrm{CV}$. Bersaudara Palembang dalam upaya mencari jalan keluar dari permasalahan yang ada.

\section{Kesimpulan.}

Pembagian kerja CV.Bersaudara Palembang, belum dilaksanakan secara jelas, hal ini terlihat tugas bagian pembukuan juga merangkap bagian penjualan barang, ini mengakibatkan tugas pembukuan semakin bertambah berat dan sudah tidak seimbang lagi dengan kemampuan dan waktu yang dimilikinya menyelesaikan tugas-tugas yang ada.

Pendelegasian atau pelimpahan wewenang CV.Bersaudara Palembang, masih belum dilaksanakan sebagaimana mestinya. Hal ini terlihat dari tugas-tugas yang semestinya dilakukan oleh bagian bendahara masih sering dikerjakan oleh pimpinan itu sendiri. Berarti disini pimpinan masih belum sepenuhnya melimpahkan wewenangnya kepada bawahannya, sebagaimana yang biasa dilakukan oleh pimpinan-pimpinan perushaan pada umumnya dengan kata lain pimpinan merasa enggan untuk melimpahkan wewenangnya kepada bawahannya, karena merasa ragu terhadap keahlian yang dimiliki oleh bawahannya. Sehingga inisiatif bawahan kurang berkembang.

\section{Saran.}

Berdasarkan kesimpulan tersebut diatas, berikut ini peneliti akan meberikan saran yang mungkin dapat digunakan sebagai bahan pertimbangan dalam usaha memajukan CV.Bersaudara Palembang yang akan datang sebagai berikut :

1. Untuk mewujudkan suatu proses manajemen yang baik, sudah waktunya menghilangkan tugas rangkap yang selama ini dikerjakan oleh bagian pembukuan. Di harapkan tidak ada lagi kesimpang siuran dalam melaksanakan tugas, memberikan kesempatan kepada bagian penjualan barang untuk melaksanakan tugas dan mempunyai rasa tanggung jawab. Selanjutnya pimpinan perusahaan 
harus jelas dan tegas dalam melaksanakan kerja pda masingmasing bawahannya. Pembagian kerja harus disertai dengan pendelegasian wewenang yang jelas dan tegas sesuai dengan fungsinya.

2. Untuk mencapai tujuan yang diharapkan, pendelegasian wewenang agar ditinjau dan di perbaiki serta diharpkan wewenang yang di delegasikan sudah sesuai dengan yang berhak menerimanya. Disamping itu inisiatif para bawahan diharapkan lebih dikembangkan sehingga pimpinan dapat lebih mengkonsentrasikan dirinya dalam melaksanakan tugasnya selaku pimpinan.

3. Pimpinan seharusnya melimpahkan sebagian wewenang kepada bawahan sesuai dengan tugastugas yang telas ditetapkan dan juga pimpinan harus menumbuhkan atau menanamkan rasa percaya ciri yang kuat terhadap bawahannya, supaya bawahan mempunyai keberanian didalam mengambil keputusan didalam menyelesaikan tugasnya, serta mempunyai percaya diri dan merasa bertanggung jawab atas pekerjaannya.

\section{DAFTAR PUSTAKA}

Alex's Nitisemito, Manajemen Suatu Dasar dam Pengantar, Ghalia Indonesia Jakarta.

Umam, Khairun. 2010. Perilaku Organisasi. Bandung: Pustaka Setia.

Riduwan. 2011. Belajar Mudah Penelitian. Bandung : Alfabeta

Fathoni Abdurahman. 2006. Organisasi dan Manajemen Sumber Daya Manusia, Jakarta: Cipta Biaga
Sobirin, Ahmad, 2007. Budaya Organisasi . Yokyakrata: STIM.YKPN

Sondang. P . Siagian (1974) Peranan Staff dalam Management. Gunung Agung: Jakarta.

Mohammad Abdul Mukhy, (1993) Pengantar Manajemen Umum, cetakan ke- dua, Gunadarma.

Manullang, M. 2008. Dasar-Dasar Manajemen. Yogyakarta: Gajah Mada University Press.

T . Hani Handoko (1985), Manajemen, Yogyakarta : BPFE

Louis, A. Allen, (1966) Karya Manajemen, (1966), Jakarta : Pt Pembangunan 